\title{
Gallbladder Adenocarcinoma with Squamous Metaplasia
}

National Cancer Institute

\section{Source}

National Cancer Institute. Gallbladder Adenocarcinoma with Squamous Metaplasia. NCI

Thesaurus. Code C9169.

An infiltrating adenocarcinoma of the gallbladder characterized by the presence of metaplastic changes of the malignant glandular cells to squamous cells. 